\title{
THE INCUBATION PROGRAMME AS AN INSTRUMENT FOR SUPPORTING BUSINESS IDEAS AT UNIVERSITY. AN EXAMPLE FROM POLAND
}

\author{
PROGRAM INKUBACYJNY JAKO INSTRUMENT WSPARCIA \\ POMYSŁÓW BIZNESOWYCH NA UCZELNI WYŻSZEJ. \\ PRZYKŁAD Z POLSKI
}

https://doi.org/10.34739/zn.2020.52.01

Joanna Rudawska

Poland, Jan Kochanowski University in Kielce, Faculty of Law and Social Sciences, ORCID: 0000-0003-1484-8283, jrudawska@ujk.edu.pl

JEL Classification Codes: M13

\begin{abstract}
People planning a business and start-up companies can use a wide range of support instruments in the first stages of their business development, the task of which is to reduce the risk associated with the implementation of a business idea. The offer available on the market includes both financial and non-financial support. One common support instrument are incubators and incubation programmes that offer assistance in the early stages of business development. Universities are an environment where incubation programmes are increasingly occupying a prominent place. They have sufficient human, organizational and administrative resources to meet the needs of innovative companies and support them with research, consultation and mentoring. The aim of this research is to discuss the typology and role of incubators in supporting business ideas and to characterise the phases of the incubation process and its models. The example of incubation programmes from Polish universities presented in the article illustrates the course of the process and the support package offered to the idea originators at a Polish university.
\end{abstract}

Keywords: pre-incubation, incubator, incubation, university-based incubator, academic entrepreneurship

\begin{abstract}
Abstrakt: Osoby planujące działalność gospodarczą, młode firmy mogą korzystać na pierwszych etapach rozwoju biznesu z szerokiego spektrum instrumentów wsparcia, których zadaniem jest zniwelowanie ryzyka związanego z realizacją pomysłu biznesowego. Dostępna na rynku oferta to zarówno wsparcie finansowe i pozafinansowe. Jednym z powszechnych instrumentów wsparcia są inkubatory i programy inkubacyjne oferujące asystę na wczesnym etapie rozwoju biznesu. Środowiskiem, gdzie pojawiają się coraz częściej są uczelnie wyższe posiadające potencjał zasobowy, organizacyjny i administracyjny, aby sprostać potrzebom innowacyjnych firm i wesprzeć je badaniami, doradztwem, mentoringiem. Celem badania jest omówienie typologii i roli inkubatorów oraz prezentacja wybranych modeli inkubacji. Zastosowano metodę przypadku, prezentując jeden z programów inkubacyjnych z Polski, obrazujący przebieg procesu i oferowany pomysłodawcom rodzaj wsparcia na polskiej uczelni wyższej.
\end{abstract}

Słowa kluczowe: pre-inkubacja, inkubator, inkubacja, uczelniany inkubator, przedsiębiorczość akademicka

\section{Introduction}

Over the last twenty years, dynamic market changes, globalisation, technological progress, and the need to support innovation have significantly changed the role and expectations of universities. Universities have been forced to broaden the range of their activities as well as open themselves up to market processes; and actively participate in them. The previous two missions performed by them, i.e. teaching and researching, have been supplemented with the third one, i.e. the capitalisation and monetisation of knowledge (Etzkowitz, 2008). Expectations towards participation in the creation and management of innovations have led the scientific sector to undertake a number of activities aimed at greater interaction along the university-industry axis. This idea, called the entrepreneurial university, has its supporters and detractors (Olearnik, PlutaOlearnik, 2016). However, universities cannot be indifferent to socio-economic changes and are increasingly assuming the role of a market entity, providing their resources in the triple helix model based on the University-Industry-Government relationship (Rudawska, 2020). The activities they 
J. Rudawska, THE INCUBATION PROGRAMME AS AN INSTRUMENT FOR SUPPORTING BUSINESS IDEAS AT UNIVERSITY. AN EXAMPLE FROM POLAND, Zeszyty Naukowe Uniwersytetu Przyrodniczo-Humanistycznego w Siedlcach Nr 125,

carry out often require changes in organisational structures, the adaptation of new marketing or financial solutions, as well as appropriate human resources. Among examples of such activities, there is the animating of academic entrepreneurship, understood as all kinds of involvement on the part of universities, students, doctoral students and academics, in the development of economic activity (Osiri et al. 2014). The aim of this article is to analyse an incubation process, different models of incubation and to present the benefits for universities of creating and supporting start-ups based on the example of an incubation programme in Poland.

\section{Incubators as a form of entrepreneurship support - literature review}

Today, universities have a wide range of possibilities to create appropriate support structures for people with business ideas or already operating start-ups. They can do this by introducing subjects related to entrepreneurship, market operation and investment, creativity and innovation into the university curricula, as well as by organising internships and apprenticeships in enterprises, employing practitioners to conduct classes and give opinions on curricula. Incubators are more advanced forms of institutional support (Wójcik-Karpacz, Rudawska, 2016).
The idea of incubators is not new. The first private incubator was established in Batavia, New York in 1959, and the first public one in Philadelphia in 1964 (Lewis, 2001). Over time, private enterprises, universities, non-governmental organisations, and local government units also became the founders of incubators. A significant increase in the number of business incubators in the world was caused, inter alia, by the fact that decision-makers recognised the role that such incubators play in stimulating economic growth, qualifying them to important elements of the regional innovation system, and the belief that incubation can act as a bridge to market entry and reduce the risk of failure (OECD 1997, UNIDO 1999).

There are various types and definitions of incubators in the nomenclature. There is also a dispute as to whether an incubator should be treated as a separate unit; or more as a kind of entrepreneurial environment, or only as a support programme (Hausberg, Korreck, 2020).

In a broader sense, the term incubator is used to describe a broad spectrum of organisations and programmes of support: from a business idea to reaching maturity and commercialisation (Fig. 1). This concept includes science and business parks, entrepreneurship centres, innovation centres, as well as business and technology incubators (European Commission, 2002).

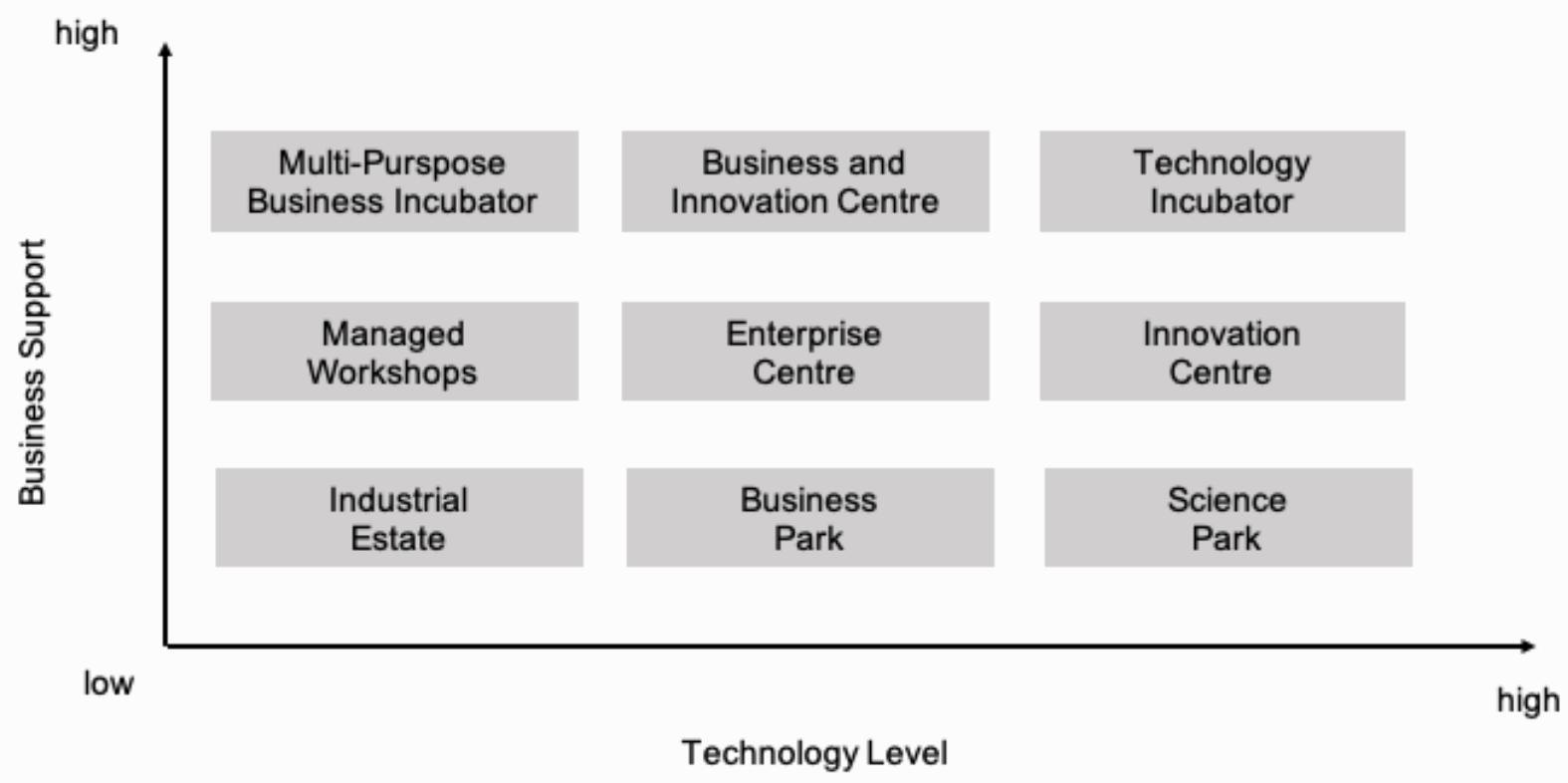

Figure 1. Forms of support for ideas at the first stage of their development

Source: own elaboration based on: Benchmarking of Business Incubators.

Final Report for the EC's Enterprise Directorate-General. European Commission, 2002. 
Individual elements are positioned according to the intensity of business support (service package) and the level of the technological advancement they offer. The least advanced form is office rental without business-related services. The most advanced form of incubation in this case is a technological incubator. However, the abovementioned forms of support may work in a variety of ways, taking into account which criteria apply to:

- for-profit or non-profit,

- university-related or non-university-related,

- share or no share / stake holding or no stake holding,

- physical institution or virtual institution (European Commission, 2002).

In a narrower sense, one can use the definition of S.M. Hackett and D.M. Dillts $(2004$, p. 55) who understand an incubator as "an enterprise that facilitates the early-stage development of firms by providing office space, shared services and business assistance". Researchers emphasise that the selection of incubated enterprises, their monitoring and the infusion of resources are essential elements of the whole process. However, according to J. Bruneel et al. (2012, p. 231), incubators are "tools to accelerate the creation of successful entrepreneurial companies", not always related to infrastructure support.

One of the types of incubators are those established at universities. University-Based Incubators (UBIs) arose from the need to involve the science sector in the active development of regional economies by creating innovative enterprises, i.e. start-ups, spin offs, and spin outs (Grimaldi, Grandi 2005). UBls differ from other business incubators in that their activities are focused on the transfer of knowledge and technology from universities to business, using the potential of students, doctoral students, and academics. UBIs are institutions which provide support and services for new knowledge-based ventures. Some researchers (Matusiak, 2001; Matusiak, Zasiadły, 2005; Mian, 2011) emphasise that incubation programmes generate a number of benefits for universities:

- improve the image of the university,

- make the educational offer more attractive,

- build relationships with the environment and local business,

- ensure financial stability,
- increase income from cooperation and technology transfer,

- provide access to advisory, training and information support,

- greater activity in acquiring projects by universities,

- additional income for students, doctoral students, researchers,

- concentration of various forms of support for entrepreneurs,

- gaining business experience by university employees.

It should be remembered that creating university start-ups requires appropriate personal skills and support programmes tailored to the type, size and specialisation of a given university.

\section{Incubation process - models' analysis}

The incubation itself can be understood as a process that can be launched whenever there is a need to encourage and support potential entrepreneurs to analyse and develop a business idea and transform it into a profitable and sustainable business; and not only as infrastructure (Wolniak, Grebski, 2018).

The entrepreneurial life cycle consists of four phases: idea, start-up, expansion and maturity, and incubators support the creation of ideas in the first stages There are very common, three phases of the incubation process:

- pre-incubation,

- incubation,

- post-incubation (Martinez, Fernandez-Laviada,

Crespo, 2017).

These three phases can be supported by the accelerator stage. Hannon (2004) uses the terminology of planned growth in order to provide a model for each stage of the incubation process (Fig. 2).

Hannon affirms that each incubator should have an adequate offer to reduce the probability of failure and undertake activities to speed up the creation of business at its all stages.

There are differences between each phase of the incubation process according to the type of entity, access to financing sources, as well as the scope of services provided by a supporting unit (Table 1). 


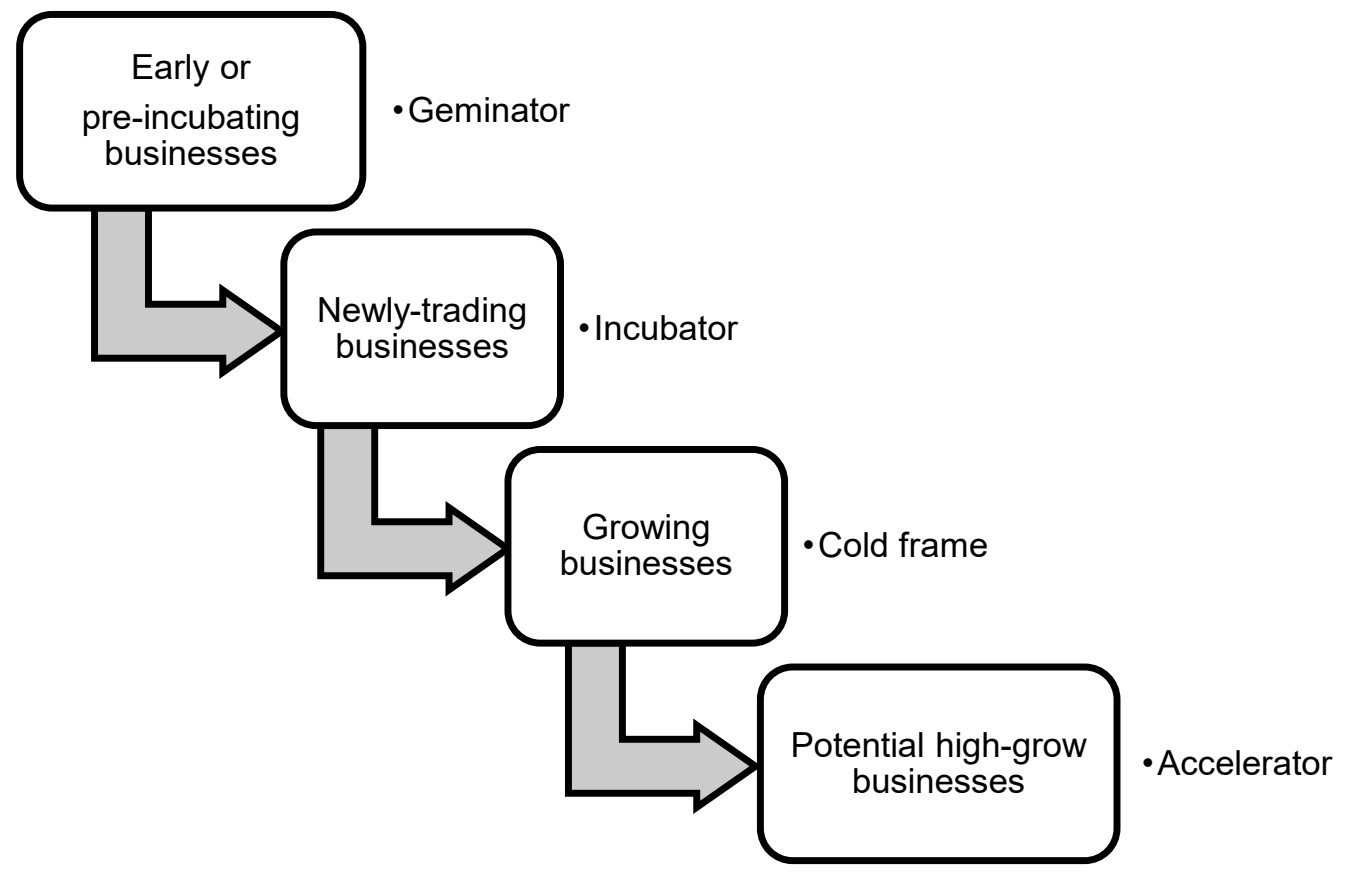

Figure 2. Stages of incubation

Source: own elaboration on the basis of Hannon, P.D. (2004), How do you want to grow your firms: natural development or battery farmed? - a reflection on the discourse of incubation', Journal of Small Business and Enterprise Development, 12(1), 57-75.

Table 1. Phases of incubation processes

\begin{tabular}{|c|c|c|c|c|}
\hline & Pre-incubation & Incubation & Post-incubation & Acceleration \\
\hline $\begin{array}{l}\text { Type } \\
\text { of entity }\end{array}$ & Natural person & $\begin{array}{l}\text { Entrepreneur (early } \\
\text { stage, start-up) }\end{array}$ & Entrepreneur & Entrepreneur \\
\hline $\begin{array}{l}\text { Boundary } \\
\text { conditions }\end{array}$ & $\begin{array}{l}\text { Initial innovative } \\
\text { business idea }\end{array}$ & $\begin{array}{l}\text { Innovative } \\
\text { product/service }\end{array}$ & $\begin{array}{l}\text { Former incubator } \\
\text { tenant status }\end{array}$ & $\begin{array}{l}\text { Innovative } \\
\text { product/service }\end{array}$ \\
\hline Period of time & Up to 6 months & $12-36$ months & Up to 12 months & 3-6 months \\
\hline Infrastructure & $\begin{array}{c}\text { Not always } \\
\text { (e.g. co-working) }\end{array}$ & Yes & Yes (e.g. laboratories) & Yes \\
\hline $\begin{array}{l}\text { Typical } \\
\text { services }\end{array}$ & $\begin{array}{l}\text { Negotiations, market } \\
\text { analysis, business } \\
\text { plan, starting a } \\
\text { business activity, } \\
\text { mentoring, networking }\end{array}$ & $\begin{array}{l}\text { Financing, consulting, } \\
\text { marketing, sales, } \\
\text { internationalisation, } \\
\text { intellectual property } \\
\text { rights, coaching, } \\
\text { mentoring, networking }\end{array}$ & $\begin{array}{l}\text { Networking, } \\
\text { consulting }\end{array}$ & $\begin{array}{c}\text { Tailor-made, } \\
\text { consulting, R\&D, } \\
\text { networking, mentoring }\end{array}$ \\
\hline $\begin{array}{l}\text { Access to } \\
\text { programme }\end{array}$ & $\begin{array}{l}\text { Free of charge } \\
\text { or subscription }\end{array}$ & Preferences & $\begin{array}{l}\text { Preferences or } \\
\text { full payment }\end{array}$ & $\begin{array}{c}\text { In return for } \\
\text { company's shares }\end{array}$ \\
\hline $\begin{array}{l}\text { Possible } \\
\text { sources of } \\
\text { financing }\end{array}$ & $\begin{array}{c}\text { 4xF (Family, Friends, } \\
\text { Fools, Fans) } \\
\text { Seed Capital } \\
\text { Business Angels } \\
\text { Crowdfunding } \\
\text { Grants }\end{array}$ & $\begin{array}{l}\text { Venture capital } \\
\text { Banks } \\
\text { Crowdfunding } \\
\text { Grants }\end{array}$ & $\begin{array}{l}\text { Private Equity } \\
\text { Venture capital } \\
\text { Bank } \\
\text { Crowdfunding } \\
\text { Grants }\end{array}$ & Venture capital \\
\hline
\end{tabular}

The pre-incubation phase includes support at the initial stage of the business idea. It includes support consisting mainly in strengthening the competences of a future entrepreneur, still as a natural person, assistance in refining the basic elements of a business model, acquiring knowledge on how to set up and run a business activity. It is not necessary to register a business 
J. Rudawska, THE INCUBATION PROGRAMME AS AN INSTRUMENT FOR SUPPORTING BUSINESS IDEAS AT UNIVERSITY. AN EXAMPLE FROM POLAND, Zeszyty Naukowe Uniwersytetu Przyrodniczo-Humanistycznego w Siedlcach Nr 125,

activity at this stage. The so-called pre-incubators are often established to offer legal and accounting support as part of a monthly subscription. According to the definition made by A. Dicson (2004), pre-incubation is "a risk-reduced environment where entrepreneurial ideas are prefiltered for market viability thus helping to avoid greater costs and failures of setting up a new company in the further phases of business development." The pre-incubator usually provides both internal and external learning venues where students and idea authors develop a new venture plan within a protective environment before committing to the risk of running a business activity.

The incubation phase, on the other hand, includes support for an already operating start-up, i.e. a registered enterprise. It is usually associated with the rental of office space, access to rooms and co-working space, as well. At this stage, a consulting support package for product or service development, as well as access to financing is provided. Contemporary incubators usually closely cooperate with venture capital funds and a team of external consultants who comprehensively support technological start-ups (Zeps and Avotins, 2010).

As part of post-incubation, ancillary services are still offered, e.g. access to laboratories, paid services. This stage is designed to increase the independence and autonomy of enterprise. This is the moment when the enterprise physically leaves the incubator and operates independently but can partly use the services the incubator provides. It usually lasts up to a year, but in the subject-matter literature one may find post-incubations which are not limited in time (lacono and Nagano, 2017). Incubators often use the name "accelerators" at this stage (Zeps and Avonis, 2012).

Acceleration is understood as an open application process for everyone, but characterised by a high degree of competitiveness in terms of the submitted applications. It gives the possibility of obtaining funds, usually in return for shares in a company. The duration of an acceleration programme for each advertised call is clearly defined and usually ranges from 3 to 6 months. Intensive mentoring sessions are a key element of each programme.
The first, second and fourth stages are preceded by the selection of candidates to be included in the support programme. Also, as a part of these programmes, especially in the case of public organisations, preferential prices are offered for individual services, and some of them may be provided by such organisations completely free of charge (Wójcik-Karpacz, Rudawska, 2016).

The holistic vision of the process was conceptualised by Campbell, Kendrick, and Samuelson (1985). The researchers suggest four areas, i.e. 1) diagnosis of business needs, 2) selection and monitoring of all services supporting enterprises, 3) capital investment, and 4) access to an expert network. The model does not take into account the lack of entrepreneurial knowledge, other capabilities or even environmental barriers, and is limited to private incubators (Moreira et al., 2012). A more external perspective, conceptualising the incubator process as a system that supports enterprises being incubated, is presented by Smilor (1987), who neglects the internal processes occurring inside the incubator and underlines the affiliation of the incubator (academic, state, private, non-profit). Smilor categorises the support system services and value-added activities for newly created enterprises according to four dimensions, i.e. 1) secretarial support, 2) administrative support, 3) facilities support, 4) business assistance.

Hackett and Dilts (2004) present the expanded model focused on the results-performance (black box) approach. They suggest that enterprises under incubation are selected from a pool of candidates, then are supported with different resources during the initial phase and are monitored on a regular basis. The outcomes refer to the survival or failure of such an enterprise (Moreira et al., 2012).

Bergek and Norrman (2008) identify in their incubation model a set of components (Fig. 3). Their model is based on that authored by Campbell, Kendrick, and Samuelson (1985). Bergek and Norrman underline that it is possible only to monitor and evaluate the performance of enterprises as well as incubators by confirming objectives and results.

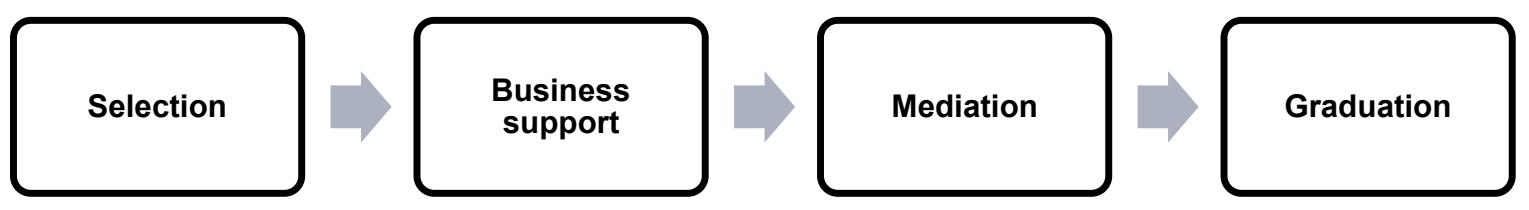

Figure 3. Bergek and Norrman (2008) incubation model Source: own elaboration. 
One of the most important stages is the selection of enterprises based on specific criteria. Infrastructure and advisory services are the business support elements. Mediation is understood as the way in which the incubator mediates the relationship between the enterprises and the external world (government, financial units, other enterprises). Leaving the incubator is regulated by the rules and moments, as well as the circumstances defined by this incubator.

\section{The example of an incubation programme run by the Warsaw University of Technology in Poland}

The incubation programme is implemented at the Warsaw University of Technology by the Centre for Innovation Management and Technology Transfer (Centre for Innovation Management...). The Centre is a combination of a modern unit and creative space, as well as modern infrastructure, which includes laboratories for R\&D works, creative rooms, conference and exhibition facilities, social and networking rooms. The aim of the Centre is to support starting, organising and running a business activity through the implementation of pre-incubation, acceleration and incubation programmes for students and academics. This action is assigned to the Innovation Incubator (ININ) established within the structure.

Students, doctoral students and researchers are offered a comprehensive programme of support from the business idea to the achieving of market stability. This offer combines an offer of usable space rental with the offer of providing services supporting the development of young innovative enterprises (General principles..., 2018). The scheme of the structure of support programmes is presented in Figure 4.

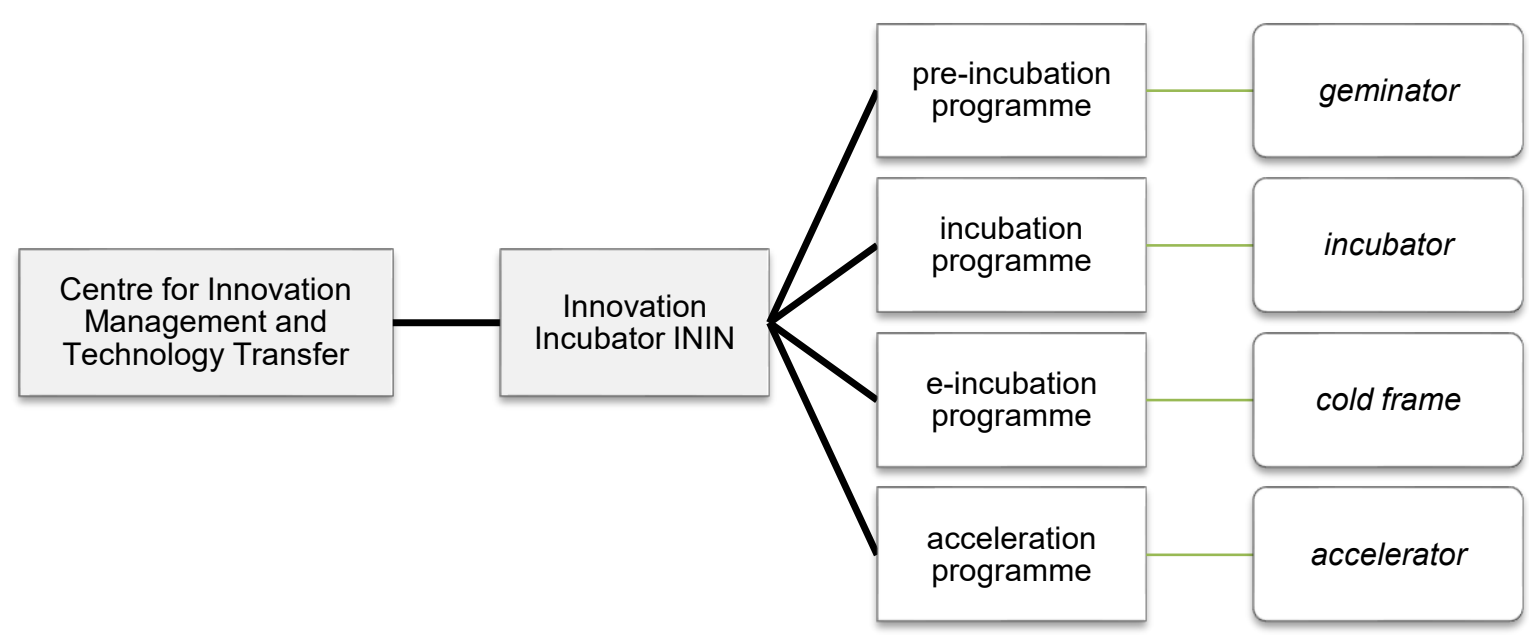

Figure 4. Organisation structure of incubation support services within Centre for Innovation Management and Technology Transfer / Warsaw University of Technology Source: own elaboration.

As a part of the pre-incubation programme "The third mission of the university - Preincubation fast start for entrepreneurial", the support is dedicated to natural persons who plan to run a business activity. The university runs different programmes that are parallel financed by an external fund. Noteworthy is that applicants must have an idea for a product or service. Such parameters as its innovativeness, the need it responds to, its scalability and the team's potential are assessed. The pre-incubation programme responds to the participants' needs, as identified earlier by the organisers. Four areas of knowledge necessary for improvement have been identified:
- business model

- business development and marketing

- product development

- sales market and investment readiness.

The two-month programme includes a series of 8 workshops and lectures, during which participants learn, among others:

- Problem Solving, Team Building

- Lean Canvas

- Customer Development

- Sales and Marketing

- MVP Building,

- Legal Forms of Business, Taxes in Enterprise

- Financing, Founders' Agreement

- Pitch, Investor Presentation. 
J. Rudawska, THE INCUBATION PROGRAMME AS AN INSTRUMENT FOR SUPPORTING BUSINESS IDEAS AT UNIVERSITY. AN EXAMPLE FROM POLAND, Zeszyty Naukowe Uniwersytetu Przyrodniczo-Humanistycznego w Siedlcach Nr 125,

In addition, the teams working in the programme can benefit from the support of team mentors and mentors from leading enterprises and institutions, who have many years of experience. They also have access to ProjectRoom space. In the final stage, each team has the opportunity to present their idea to the audience and investors during the annual "DemoDay" and additional networking activities, such as "Expert Day" and "InspireDay". Participation in the programme is free of charge, registration is made voluntarily, and activities are carried out alongside the curricular activities, and treated as additional.

From 2019 to 2020, 4 editions of the preincubation "The third mission of the university Preincubation - fast start for entrepreneurial" were held at Warsaw University of Technology, two per year. Each of them lasted for 2 months (8 weeks).

According to the model by Bergek and Norrman (2008), the incubation process at the Warsaw University of Technology covers all stages; but what is important to underline the three phases pre-incubation, incubation and post-incubation are functioning separately and are supported by different external sources mostly from European Union funds. Each phase (pre-incubation, incubation, post-incubation) consists of selection, business support, mediation and graduation. Figure 5 presents the pre-incubation programmes implemented at university within the project. In total, 76 people have benefited from whole support so far, but the number of applications submitted was much higher (Table 2).

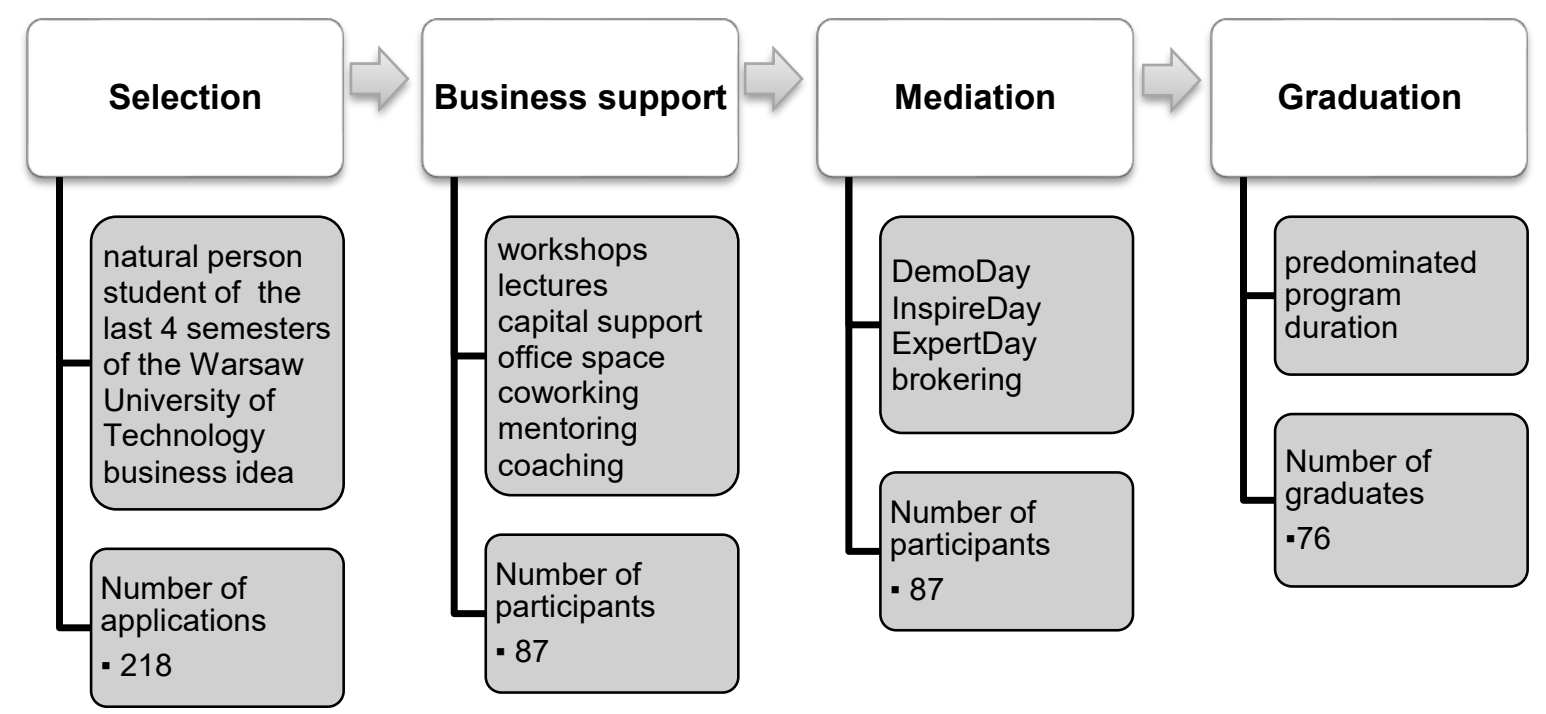

Figure 5. Preincubation model at Warsaw University of Technology within the project "The third mission of the university - Preincubation - fast start for entrepreneurial" Source: own elaboration.

Table 2. Statistics of the pre-incubation project "The third mission of the university - Preincubation - fast start for entrepreneurial"

\begin{tabular}{c|c|cccc|cccc}
\hline & & \multicolumn{6}{|c|}{ People accepted into the programme } & \multicolumn{2}{c}{ People who completed the programme } \\
\cline { 3 - 9 } Edition & $\begin{array}{c}\text { Submitted } \\
\text { applications }\end{array}$ & $\begin{array}{c}\text { Number of } \\
\text { participants }\end{array}$ & Female & Man & $\begin{array}{c}\% \text { of } \\
\text { applicants }\end{array}$ & $\begin{array}{c}\text { Number of } \\
\text { participants }\end{array}$ & $\begin{array}{c}\text { Female } \\
\text { Man of } \\
\text { accepted } \\
\text { into the } \\
\text { programme }\end{array}$ \\
\hline $2019 \# 1$ & 57 & 16 & 3 & 13 & 28 & 14 & 2 & 12 & 87 \\
$2019 \# 2$ & 49 & 26 & 14 & 12 & 53 & 18 & 9 & 9 & 69 \\
$2020 \# 3$ & 92 & 34 & 17 & 17 & 37 & 34 & 17 & 17 & 100 \\
$2020 \# 4$ & 20 & 11 & 8 & 3 & 55 & 10 & 8 & 2 & 91 \\
\hline Total & 218 & 87 & 42 & 45 & 40 & 76 & 36 & 40 & 87 \\
\hline
\end{tabular}


J. Rudawska, THE INCUBATION PROGRAMME AS AN INSTRUMENT FOR SUPPORTING BUSINESS IDEAS AT UNIVERSITY. AN EXAMPLE FROM POLAND, Zeszyty Naukowe Uniwersytetu Przyrodniczo-Humanistycznego w Siedlcach Nr 125,

As part of the pre-incubation programme, 4 editions, only $40 \%$ of applicants were accepted. The limitations are caused by both the boundary conditions of entering the programme and the limitations of places. Those who completed the programme constituted $87 \%$ of all those who qualified for it, which means that during its duration $13 \%$ quit for different reasons. The numbers of men and women in the programme were almost the same.

By completing the pre-incubation, participants have the opportunity to continue to develop their idea, after starting a business activity, as part of the incubation programme of the Innovation Incubator of the Warsaw University of Technology or e-incubator programme. The Warsaw University of Technology offers a two-year incubation programme addressed to technology enterprises, start-ups and enterprises important for the development of the university's innovation ecosystem. As part of the incubation, enterprises can receive help in building markets for services and products, and in obtaining financing necessary for further development. They can also rent space, have access to a car park, internet, conference zone, and advisory services provided by external experts. The offer is a part of the Innovation Incubator + project, whose goal is to manage the results of scientific research and development works, in particular in the field of commercialisation. What is worth mentioning is the fact that from the pre-incubation programmes at the University only one business idea decided to run a business in the incubator. Those who want to cooperate with Technology University longer, can use the e-incubator, giving the possibility to use a registered office address without renting space, together with limited support services. People looking for support while commercialising a venture, who have a patent or a new technology, can take advantage of expert services as part of acceleration.

The programme provides comprehensive support at the first stage of idea development and gives the opportunity to test this idea in real and safe conditions. It reduces the risk of failure and, at the same time, raises the qualifications of originators and increases their chances of succeeding in a mature market as an entrepreneur. Enterprises maintain constant relations with the environment through organised events and the testing of products and services. all programmes implemented at the university should be monitored and allow for a smooth transition of business ideas into the next phases. Currently, projects carried out separately, and in parallel, which do not overlap, have different entry conditions, which makes it difficult to assess the effects of the entire incubation programme; and not its individual phases of pre-incubation, incubation, post-incubation.

\section{Conclusions}

Incubators allow for reducing the risk of business failure, verifying the commercial potential of a business idea and preparing the groundwork for an enterprise. In the subject-matter literature, there are many types and definitions of incubators as an element of the network of innovation and entrepreneurship centres. One can distinguish two approaches to incubation as a process carried out by various types of institutions, such as universities, technology parks, entrepreneurship centres, innovation centres in the form of the incubation programmes with a specific structure and support package, as well as the approach to the incubator as a business environment institution, being an independent and separate structure implementing support. In both cases, incubation consists of the three main phases of pre-incubation, incubation and post-incubation, often supplemented by an acceleration phase, thanks to which ideas and enterprises can be supported at different stages of development. These phases may be carried out by various either jointly or seperately. They play a special role at universities thanks to their access to human resources and potential originators of innovative ventures. The catalogue of services provided by incubators may differ depending on the specialization of the university, the faculty at which it is appointed, as well as a strategic business partner or the industry dominating in the region. However, basic knowledge, such as preparation for running a business, verification of the business model, soft skills such as presentations, including investor ones, remain an integral part of the programme, which, even after leaving the university walls, will be useful for graduates on the market.

Incubation programmes are now an elementary part of entrepreneurship education at universities. This is due to the role that each university should play, i.e. promoting entrepreneurship, encouraging the starting of a business activity, and supporting the entrepreneurial behaviour, skills and perceptions among individuals. Qualified university employees, technical infrastructure for programme participants, as well as an appropriate formal and legal organisation and management system, are the challenges faced by universities striving to implement the "third mission" by launching and running incubators. It also is clear that this form of 
J. Rudawska, THE INCUBATION PROGRAMME AS AN INSTRUMENT FOR SUPPORTING BUSINESS IDEAS AT UNIVERSITY. AN EXAMPLE FROM POLAND, Zeszyty Naukowe Uniwersytetu Przyrodniczo-Humanistycznego w Siedlcach Nr 125,

support will generate a number of benefits for each university, not only in terms of image.

The example of Warsaw University of Technology presents a model catalogue of support offered in this type of institution or programme. It shows the necessity to combine the activities carried out at the university by different departments within parallel projects. It presents also the need to separate an organizational structure for the implementation of pre-incubation, incubation and post-incubation, and provides an example of a comprehensive training, consulting and mentoring offer.

It is worth undertaking further research on the criteria for verifying business ideas at the entrance to incubators, the indicators of monitoring their development, as well as the rate of survival and further fate of enterprises following their deprature from the incubation programme.

\section{References}

Bergek, A., Norrman, C. (2008). Incubator Best practice: A framework. Technovation, 28(1/2): 20-28.

Campbell, C., Kendrick R. \& Samuelson, D. (1985). Stalking the Latent Entrepreneur. Economic Development Review, 3(2): 43-48.

Centre for Innovation and Technology Transfer Management of Warsaw University of Technology, https://www.cziitt.pw.edu.pl/ inkubator/ preinkubacja/ - retrieved on 20.05.2020.

Dickson, A. (2004). Pre-incubation and the New Zealand business incubation industry. Centre for SME Research, Massey University: Wellington.

Etzkowitz, H. (2008). The Triple Helix - University - Industry - Government Innovation in Action. Routledge: New York.

European Commission (2002). Benchmarking of Business Incubators. Final Report for the EC's Enterprise Directorate-General. www.op.europa. edu/en-retrieved on 20.05.2020.

Grimaldi, R. Grandi, A. (2005). Business incubators and new venture creation: an assessment of incubating models, Technovation 25(2): 111-121. DOI: 10.1016/S0166-4972(03)00076-2.

Hackett, S.M., Dilts, D.M. (2004). A systematic review of business incubation research. Journal of Technology Transfer, 29(1): 55-82. DOI: 10.1023/B:JOTT.0000011181.11952.0f.

Hannon, P.D. (2004). How do you want to grow your firms: natural development or battery farmed? - a reflection on the discourse of incubation'. Journal of Small Business and Enterprise Development, 12(1): 57-75.
Hausberg, J.P., Korreck, S. (2020). Business incubators and accelerators: a co-citation analysis-based, systematic literature review. The Journal of Technology Transfer (45): 151-176. DOI: 10.1007/s10961-018-9651-y.

lacono A.M.S. (2017). Pós-incuba o de empresas de base tecnológica: um estudo de caso sobre o efeito da incubadora nos padr es de crescimento Gest. Prod., S o Carlos 24(3): 570-581. DOI:10.1590/0104-530X1357-16.

Martínez, K.R.G, Fernández-Laviada, A., Crespo, A.H. (2017). Influence of Business Incubators Performance on Entrepreneurial Intentions and its antecedents during the Pre-Incubation Stage, Entrepreneurship Research Journal, De Gruyter, 8(2): 1-15. https://ideas.repec.org/a/ bpj/erjour/v8y2018i2p15n2.html.

Matusiak, K.B. (2001). Uczelniany inkubator przedsiębiorczości [Third-Level Campus Enterprise Incubator]. In: Szabłowski, J. (Ed.), Edukacja dla rozwoju innowacyjnego w Polsce [Education for Innovative Development in Poland]. KRUN Publishing House, Warsaw-Białystok (pp. 187-196).

Matusiak, K.B., Zasiadły, K. (2005). Rekomendacje dla Polski [Recommendations for Poland] in: Guliński, J., Zasiadły, K. (Eds.), Innowacyjna przedsiębiorczość akademicka - światowe doświadczenia, [Innovative Academic Entrepreneurship - World Experience]. Polish Agency for Enterprise Development, Warsaw.

Mian, S.A. (2011). University's involvement in technology business incubation: what theory and practice tell us? International Journal of Entrepreneurship and Innovation Management, 13(2): 113-121. DOI: 10.1504/IJEIM.2011. 038854.

Moreira, A.C., Marta, F.S., Carvalho, M.F.S. (2012). Incubation of new ideas: extending incubation models to less favored regions. In T. Burger-Helmchen (Ed.), Entrepreneurship, Creativity and Innovative Business Models (pp. 41-58). DOI:10.5772/36705.

OECD (1997). Technology Incubators: Nurturing Small Firms. Paris: Organisation for Economic Co-operation and Development. http://www. oecd.org/science/inno/2101121.pdf.

Ogólne zasady funkcjonowania Inkubatora Innowacyjności Politechniki Warszawskiej z funkcją preinkubatora Centrum Innowacji i Transferu Technologii Politechniki Warszawskiej. [General Principles of Operation of the Innovation Incubator of the Warsaw University of Technology with the Function of a Pre-incubator Centre for Innovation and Technology Transfer of Warsaw University of Technology] 2018. Retrieved from https://www.cziitt.pw.edu.pl/wpcontent/uploads/2015/09/20180518_Ogloszenie 
_Załącznik-nr-2_Ogólne-zasady-funkcjonowania-ININ-1.pdf.

Olearnik, J., Pluta-Olearnik, M. (2016). Uniwersytet przedsiębiorczy - herezja czy nowa orientacja uczelni? [Entrepreneurial University - heresy or the new orientation of the university?]. Horizons of Education, 15(35): 5571. DOI:10.17399/ HW.2016.153503.

Osiri, J.K. Miller D.R., Clarke L., Jessup L. (2014). Academic entrepreneurship: technology transfer in higher education. Journal of Entrepreneurship Education, 17(1): 39-61.

Rudawska, J., (2020). Rola społeczeństwa obywatelskiego w tworzeniu innowacji - helisy jako modele innowacji regionalnych, [Role of Civil Society in Creating Innovation - Helices as Models of Regional Innovation] in: A. Anna Olejniczuk-Merta, M. Miller (Eds.), Innowacje społeczne. Od aktywizacji społeczeństwa do ekosystemu innowacji (pp. 77-91). [Social Innovations. From Activating Society to the Innovation Ecosystem]. Warsaw: Kozminski University, Key Text sp. z o.o. Publishing House.

Smilor, R.W. (1987). Managing the Incubator System: Critical Success Factors to Accelerate New Company Development. IEEE Transactions on Engineering Management, 34(4): 146-156.

UNIDO (1999). In-depth evaluation of selected UNIDO activities on the development and transfer of technology: Component 3: Technology Business Incubators. Retrieved from www.open.unido.org.
Wójcik-Karpacz, A., Rudawska, J. (2016). Instytucjonalne formy wspierania przedsię-biorczości w Polsce. [nstitutional Models of Entrepreneurship in Poland], Research Papers of Wrocław University of Economics, (419): 248-416. DOI: 10.15611/pn.2016.419.22.

Wolniak, R., Grebski, M.E. (2018). Comparative Analysis of the Level of Satisfaction with the Services Received at the Business Incubators in USA and Poland - pre-incubation and incubation stage. Production Engineering Archives, (20): 38-42. Retrieved fromhttp:// yadda.icm.edu.pl/yadda/element/bwmeta1.ele ment.baztech-370bd64a-f7fb-49ed-be31-6192 caa30440/c/2018_20_PEA_08.pdf.

Zeps, V., Avotins, V. (2010). Critical Conditions to Establish Efficient Incubation Cycle in Latvia, Conference: XXI ISPIM Conference "Dynamics of Innovation". Retrieved from https://www.researchgate.net/publication/208349346_Critical_ Conditions_to_Establish_Efficient_Incubation_ Cycle_in_Latvia.

Zeps, V., Avotins, V. (2012). Post-incubation impact on high growth startups, Conference: The XXIII ISPIM Conference - Action for Innovation: Innovating from Experience - in Barcelona, Spain on 17-20 June 2012. Retrieved from https://www.researchgate.net/publication/3199 13848_Post-incubation_impact_on_high_ growth_start-ups. 